LULAC 


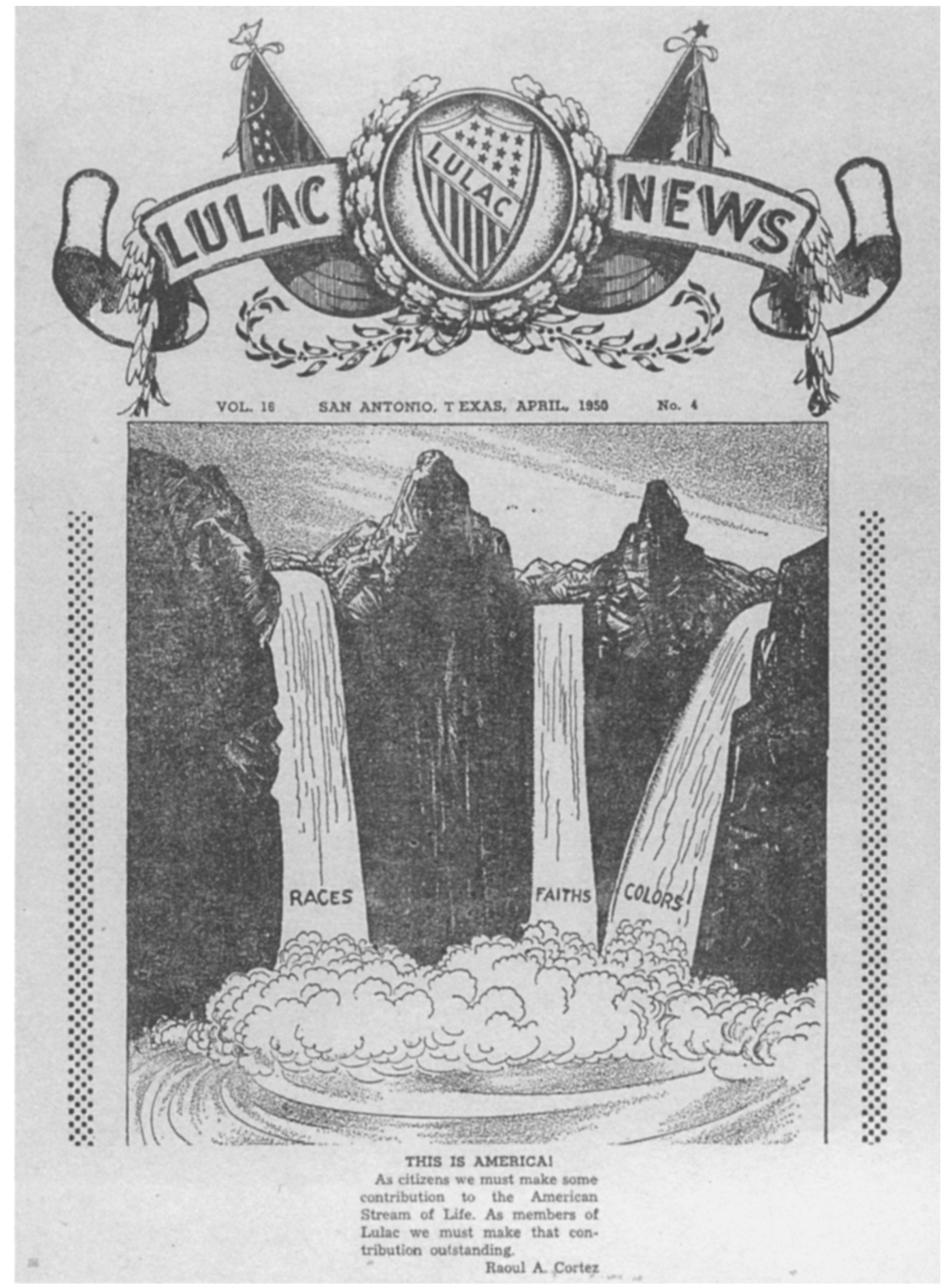

Cover of the LULAC News, Vol. I6, No. 4 (April I950). 


\section{The Evolution of a Mexican}

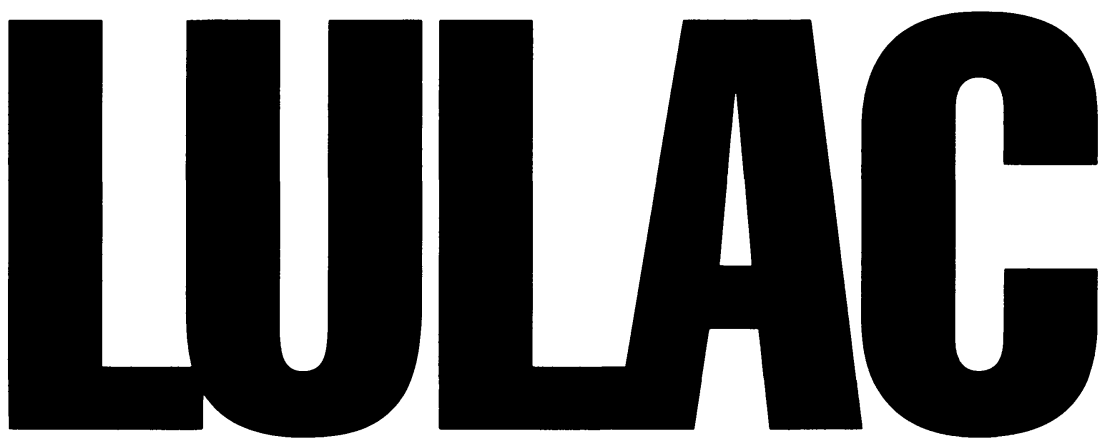

American Political Organization

Benjamin Márquez

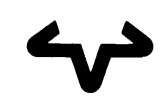

University of Texas Press, Austin 
Copyright $\mathbb{C} 1993$ by the University of Texas Press

All rights reserved

First edition, 1993

Requests for permission to reproduce material from this work should be sent to Permissions, University of Texas Press, Box 7819, Austin, TX 78713-7819.

(2) The paper used in this publication meets the minimum requirements of American National Standard for Information Sciences-Permanence of Paper for Printed Library Materials, ANSI Z39.48-I 984 .

All illustrations are from the Nettie Lee Benson Latin American Collection, General Libraries, The University of Texas at Austin. Used with permission.

Grateful acknowledgment is made to the following for permission to quote from copyrighted material.

Social Science Journal: For material from Márquez, Benjamin, "Organizational Maintenance and the League of United Latin American Citizens." Social Science Journal 28, no. 2 (April 1991).

Social Science Quarterly: For material from Márquez, Benjamin, "The Politics of Race and Class: The League of United Latin American Citizens in the Post-World War II Period." Social Science Quarterly 68, no. I (March I987).

Western Political Quarterly: For material from Márquez, Benjamin, "The Politics of Race and Assimilation." Western Political Quarterly 42, no. 2 (June I989).

\section{Library of Congress Cataloging-in-Publication Data}

Márquez, Benjamin, date.

LULAC : the evolution of a Mexican American political organization /

Benjamin Márquez.—Ist ed.

p. $\mathrm{cm}$.

Includes bibliographical references and index.

ISBN 0-292-75 I 54 -O (pbk.)

ISBN 0-292-75 I 52-4 (alk. paper)

I. League of United Latin American Citizens. 2. Mexican AmericansPolitics and government. I. Title.

EI 84.M5M357 I 993

$322.4^{\prime} 089^{\prime} 6872073$-DC2O

$92-28983$ 
To Lolita, Carlos, Carina, and Antoñio 
THIS PAGE INTENTIONALLY LEFT BLANK 